\title{
The Influence of E-Commerce on the Foreign Trade of Shanghai Free Trade Zone*
}

\author{
Xinxin MA ${ }^{1}$, Fan ZHANG ${ }^{2}$
}

Received: June 12, 2020. Revised: July 06, 2020. Accepted: August 05, 2020

\begin{abstract}
Purpose: As one of the most developed cities in China, the application of e-commerce is more mature, especially the promotion of ecommerce to foreign trade. After the establishment of Shanghai Free Trade Zone (FTZ) in 2013, the government issued a series of policies to promote the application of e-commerce in Shanghai's foreign trade. This paper takes Shanghai FTZ as an example to study how to develop the application of e-commerce in other free trade zones and how to innovate the international trade mode. Research design, data and methodology: This paper selects the latest data from 2010 to 2019, uses econometric correlation analysis and regression analysis to study the impact of e-commerce on the foreign trade of Shanghai FTZ. Results: At last, the conclusion is drawn that the establishment of free trade zone provides many advantages for the development of e-commerce in Shanghai, and the growth of e-commerce in Shanghai FTZ promotes the development of foreign trade of Shanghai FTZ. Conclusions: So as to promote the development of e-commerce in Shanghai Free Trade Zone, some suggestions are put forward, such as increasing network supervision, establishing e-commerce talent training system, logistics management and information management systematization.
\end{abstract}

Key words: Shanghai FTZ, Electronic Commerce, International Trade, Empirical Study

JEL Classification Code: F12， F124.

\section{Introduction}

The application of e-commerce has become an important way for many developed countries and developing countries to conduct international trade. Compared with other developed countries, China's ecommerce started late, but it has a strong momentum of development. Relevant researchers predict that China's e-

* Fund Project: Social science planning fund project of Shandong Province: Research on the transformation and upgrading of Shandong free trade zone to "free trade zone" under the background of digital trade.

2 First Author, Students, Shandong University of political science and law China, Email: xinnxinnm@126.com

3 Corresponding Author, Lecturer, Shandong University of political science and law, China, Email: zhafafa@126.com

(c) Copyright: The Author(s)

This is an Open Access article distributed under the terms of the Creative Commons Attribution Non-Commercial License (https://creativecommons.org/licenses/by-nc/4.0/) which permits unrestricted non-commercial use, distribution, and reproduction in any medium, provided the original work is properly cited. commerce still has great potential in the development of international trade. How to continuously promote and improve the application of e-commerce is a problem that many scholars and government personnel have explored in recent years. According to the relevant data, affected by the global economic situation, the development of China's international trade shows a weak state, while in recent years, the scale of cross-border e-commerce transactions based on e-commerce shows a gradual growth trend, thus promoting the development of China's international trade. Therefore, the development of e-commerce has an impact on the trading mode, payment mode and logistics supervision mode of import and export trade in Shanghai Free Trade Zone, thus promoting the development of import and export trade in Shanghai free trade zone. At the same time, the construction of Shanghai free trade zone and the implementation of many policies are conducive to the development of e-commerce, the application and innovation of e-commerce in international trade in Shanghai Free Trade Zone, thus promoting the development of foreign trade, which also provides experience and reference for other free trade zones. This paper is divided into five parts, 
the first part is the literature review at home and abroad; the second part is the research background of this paper, including the overview of e-commerce, the concept and characteristics of free trade zone; the third part discusses the application of e-commerce in Shanghai Free Trade Zone in foreign trade, and lists the impact of e-commerce in Shanghai Free Trade Zone on its foreign trade enterprises. The fourth part selects the latest data from 2010 to 2019, uses econometric correlation analysis and regression analysis to study the impact of e-commerce on the import and export trade of Shanghai free trade zone. The fifth part comprehensively considers the related research results of the first four parts, and puts forward some policy suggestions aiming at promoting the development of Shanghai's foreign trade.

\section{Literature Review at Home and Abroad}

The popularity and development of the Internet and computer provide the precondition for the emergence of ecommerce. With the emergence of e-commerce, the way of trade between countries has changed quietly, which has caused the research of scholars at home and abroad.

\subsection{Domestic Literature Review}

Different scholars have done different depth and direction research on the impact of e-commerce on international trade and the future development trend of international trade. Yang and Meng (2012) analyzed the impact and application of e-commerce on international trade, and concluded that the future development trend of international trade is paperless trade. Wei (2016) studies that the relationship between China's total international trade volume and its total e-commerce volume is in a longterm equilibrium state. As long as the e-commerce volume increases by one unit, China's import and export volume will increase by 0.04031 units, which shows that the application of e-commerce in foreign trade enterprises can promote the development of China's import and export trade, and e-commerce is China's trade An important driving force of development is the mutual influence between the growth of China's import and export trade and the development of e-commerce. Wei (2017) believes one belt, one road and other policies will promote cross-border e-commerce to change the pattern of foreign trade, especially the international competitiveness of small and medium-sized foreign trade enterprises in China, so that China's foreign trade will take an advantage in a complex international trade environment. Fan Mengnan and Chi (2019) put forward suggestions to promote the development of international trade through the analysis of the impact of e-commerce on international trade.

With regard to the research on Shanghai Free Trade
Zone, Yu and Ling (2014) analyzed the development of cross-border e-commerce in the early stage of the establishment of Shanghai free trade zone. They believed that the advantages of "cross-border communication" were not fully exerted. To solve the problems existing in crossborder e-commerce in Shanghai free Trade Zone, it needs the change of consumers' ideas, the conscious standardization of sellers and the continuous support of national policies. Chen (2015) takes the cross-border ecommerce of Shanghai free trade zone as the main research object, analyzes and explores the existing advantages of the development of cross-border e-commerce in Shanghai free trade zone according to the bilateral market theory, and believes that it is necessary to build an e-commerce Industrial Park, and use various preferential policies of Shanghai city to provide support for the application of ecommerce in international trade. Qiao (2016) found that the regional and policy advantages of Shanghai Free Trade Zone largely solved the existing problems of cross-border e-commerce in China. Wang (2018) analyzed the impact of cross-border e-commerce in the free trade zone on international trade in each free trade zone, and the impact of cross-border e-commerce nationwide on China's international trade. Through comparative study, we can see that the development of cross-border e-commerce in the free trade zone has a more stimulating effect on the development of China's international trade.

\subsection{Literature Review of Foreign Countries}

Compared with the research in China, the related research abroad is more extensive and profound. This paper selects three articles to summarize. Nuray (2011) concluded that e-commerce can bring economic benefits to all countries. In the short term, interests may be more concentrated in developed countries, but in the long run, developing countries will gain more. Gomez-Herrera, Martens, and Turlea (2014) found that online trade provides a comparative advantage for exporting countries. Guy and Snodgrass (2015) believe that the growth of e-commerce sales is faster than that of non e-commerce sales, and the development of e-commerce provides opportunities for small and medium-sized enterprises to expand the number of sellers and smoothly enter the international market.

\section{Research Background}

\subsection{Overview of E-Commerce}

E-commerce is called e-commerce for short. It is a new trade way based on computer network tools. For ecommerce, we should combine the two concepts of modern information technology and business to understand. In a 
broad sense, e-commerce is a new business model and technical information means. In a narrow sense, it is a kind of trading way that enterprises use network tools to trade products.

Cross border e-commerce refers to the cross-border economic activities of different subjects, the use of ecommerce for international trade, that is, the display of goods in trade, trade negotiations, payment and other links with the help of the Internet for electronic, through the international logistics distribution of goods a trade model. E-commerce and cross-border e-commerce are inclusive and inclusive relationships. Cross border e-commerce is based on the development of e-commerce. The development of e-commerce is the fundamental reason to drive the development of cross-border e-commerce related industries, such as cross-border platform construction, cross-border logistics and distribution, cross-border payment application and other fields. The premise of crossborder e-commerce transactions is that the subjects of economic activities cross the border. The application of ecommerce by foreign trade enterprises includes not only cross-border transactions, but also the purchase of domestic goods and the management of enterprises, which will affect the search cost, information cost and bargaining cost of enterprises, and ultimately affect the import and export trade of the country. Therefore, the impact of e-commerce on foreign trade enterprises includes not only the traditional trade mode, but also the production, management and operation of the company.

\subsection{Overview of Free trade Area}

With the establishment of Shanghai Free Trade Zone, the concept of free trade zone has gradually entered our vision. Free trade area is generally in two forms, one is the cross-country regional type, which refers to the crossborder bilateral economic and trade area formed by two or more countries through some kind of free trade agreement. The purpose is to realize the self-determination of foreign trade and investment, eliminate trade barriers between member countries, expand market openness and reduce market access conditions So as to form regional economic integration. This kind of free trade zone mainly includes the European Union, North American Free Trade Organization, etc. Another kind of free trade zone (FTZ) is the type of domestic and foreign customs, which refers to a specific region designated by a country or region within its jurisdiction. This region is mainly managed by developing trade, and implements trade preferential policies or special regulatory policies. The purpose of the two kinds of free trade zones is to develop and promote international free trade. Although the two types of free trade zones are the same in concept, they are different in essence. The first is the regional economic cooperation group formed by many countries in the context of economic globalization, which aims to develop for the common interests. The second is a specific non-tariff area designated by a country for the purpose of its foreign trade development.

Shanghai free trade zone belongs to the second type mentioned above. Shanghai free trade zone has been established since 2013, covering seven areas including Shanghai Waigaoqiao Free Trade Zone, Waigaoqiao Free Trade Logistics Park and Yangshan Free Trade Port. Looking up relevant materials, we can see that the planning and construction of Shanghai Free Trade Zone focuses on Waigaoqiao Free Trade Zone of Shanghai as the center and other regions as the auxiliary, and implements innovative supervision service mode, so as to simplify supervision procedures, reduce relevant costs and achieve the purpose of "domestic and foreign customs". It is in line with the trend of economic globalization and the need to further expand reform and opening up. In addition, from the general plan of China (Shanghai) pilot Free Trade Zone, we can see the orientation of Shanghai Free Trade Zone, which is to play a demonstration role for other regions in China, and to extend its various experiences to other regions in China. More importantly, reading the relevant policy documents of Shanghai Free Trade Zone, we can see that the development of e-commerce is still a government encouraged project. The construction of Shanghai free trade zone has implemented a series of innovative measures to promote the development of e-commerce, so as to promote the upgrading and transformation of international trade, thus promoting the economic development of the country, and also providing reference for the construction of other free trade zones.

\section{Development Status of E-Commerce in Shanghai Free Trade Zone}

\subsection{Development Status of E-Commerce in Shanghai Free Trade Zone}

From the current situation of e-commerce development in each province, Shanghai is one of the leading provinces of e-commerce development in China. According to the data provided by the Shanghai Municipal Commission of Commerce, the e-commerce transaction volume of Shanghai increased year by year from 2011 to 2019. The ecommerce transaction volume of Shanghai reached 3318.6 billion yuan from 425.3 billion yuan in 2010 to 2019 . The e-commerce transaction volume of Shanghai in 2019 increased by $14.5 \%$ year on year compared with 2018 , which shows that the E-commerce development momentum of Shanghai in recent years is strong, and there is still a lot of room for the development of e-commerce in the future. 
According to the data of China e-commerce research center, there are 131 e-commerce investment and financing events in Shanghai in 2019, with a financing amount of about 35 billion yuan. It can be seen from the statistics of China ECommerce Research Center that the number of e-commerce investment and financing events in Shanghai is second only to Beijing, ranking second in China's provinces, which shows that the development prospect of e-commerce in Shanghai is good for the majority of investors, and the development status is more than other cities For maturity. E-commerce has become an important driving force for Shanghai's innovation driven development and economic transformation, which is closely related to the construction of Shanghai free trade zone and various government incentives. One belt, one road and other policies, coupled with the construction of cross-border e-commerce platform in Shanghai free trade area and government innovation initiatives and policies, are the core of the development of e-commerce in the free trade area of Shanghai. These provide convenience for the continuous expansion and development of cross-border electricity providers. In August 2019, the measures for the administration of the new area near the port of China (Shanghai) pilot free trade zone was published, in which Article 16 pointed out that in order to promote the development of cross-border ecommerce, cross-border digital trade should be developed, cross-border e-commerce service mode should be innovated, and the establishment of international distribution platform should be encouraged, which showed that in the face of complex domestic and foreign economic situation, Shanghai municipal government still tends to drum up its policies Encourage the development and innovative application of cross-border e-commerce, so as to promote the domestic economic development.

Although the Shanghai municipal government is committed to improving and promoting the application of e-commerce in foreign trade, there are still some problems. First, cross-border logistics is inefficient but costly. The international logistics of Shanghai free trade zone has the defects of small scale, low specialization, low efficiency and high cost, which limits its development. Secondly, the construction of the platform still needs to be improved. The e-commerce platform built in Shanghai free trade zone is not only a trading platform, but also includes payment, customs clearance, commodity inspection, logistics, etc., which can simplify the procedures and facilitate the supervision of the government. Finally, there is a lack of compound professionals. To develop the application of ecommerce in international trade, the relevant personnel are required to not only master the theoretical knowledge of ecommerce and international trade terms, but also master the foreign trade process in e-commerce and the policies for cross-border e-commerce in the free trade zone. Therefore, the requirements for relevant talents are high, and the training of employees is not comprehensive enough.

\subsection{The Influence of E-commerce Development in Shanghai Free Trade Zone on Foreign Trade Enterprises}

The development and application of e-commerce in Shanghai free trade zone has also brought different degrees of influence to foreign trade enterprises, including changes in foreign trade mode, payment mode, business management mode, etc. The establishment of cross-border e-commerce platform in Shanghai free trade zone and various government support policies have promoted Shanghai foreign trade enterprises to use e-commerce to save costs and develop foreign trade.

\subsubsection{Reduction of Trading Links}

At present, as a new trade mode, cross-border ecommerce is in a rapid development stage in China. The phenomenon of "purchasing on behalf of others" and "overseas shopping" is in confusion, and the industry behavior is lack of norms. The construction of Shanghai free trade zone has played a positive role in transforming this integrated system. As a national cross-border ecommerce pilot, Shanghai free trade zone has attracted hundreds of foreign trade enterprises to settle down through the establishment of cross-border e-commerce platform. As shown in Figure 1, compared with the traditional foreign trade process, cross-border e-commerce platform can greatly reduce the trading links of foreign trade enterprises, thus saving the cost of enterprises and improving their competitiveness.

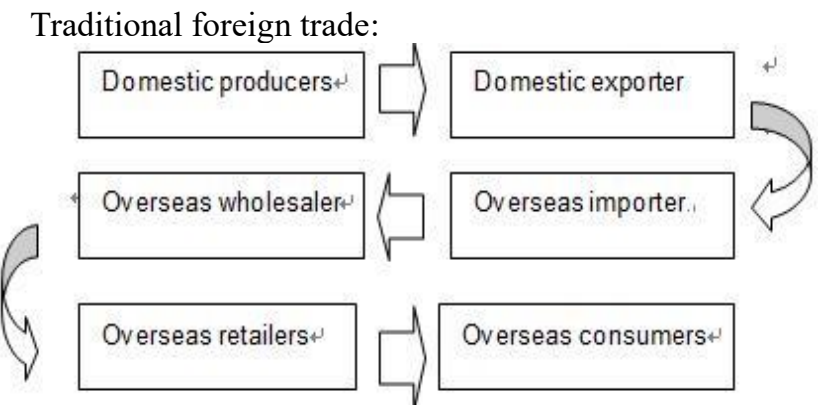

Cross border E-commerce:

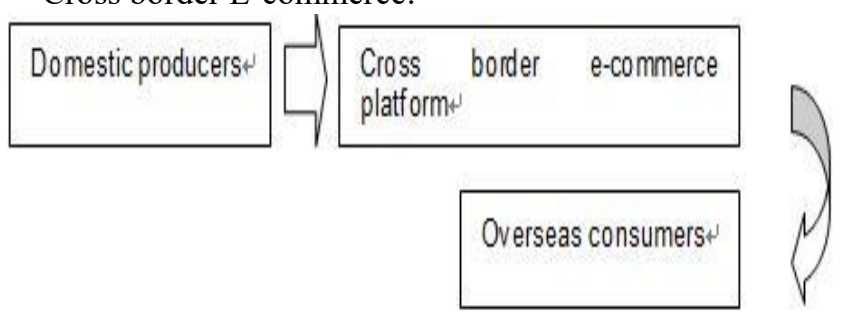

Figure 1: Comparison of transaction process between traditional foreign trade and cross-border e-commerce in Shanghai 


\subsubsection{Convenience of Means of Payment}

With the development of e-commerce in Shanghai Free Trade Zone, foreign trade enterprises rely on the advantages of the Internet of e-commerce platform, and get rid of the disadvantages of cumbersome payment steps and sometimes sluggish capital to account. Taking "cross border communication" as an example, it has changed the past problems such as insecure online payment and insecure return of goods, so that consumers can buy more safely. "Cross border communication" relies on the third payment platform Oriental payment, which has obvious competitive advantages. However, because it only has one payment method of Oriental payment, consumers who do not have a payment account give up buying.

\subsubsection{Reduce Operating Costs}

As cross-border e-commerce transactions need to cross national boundaries, a long-term problem for local enterprises is that after-sales services cannot be guaranteed. The construction of Shanghai free trade zone provides a buffer zone for such enterprises, helps enterprises improve the offline service system, and saves financial and logistics costs through the free trade zone, which increases the competitiveness of local companies. For overseas companies, in the past, if they want to enter the Chinese market to sell their products, they need a lot of money to open promotion channels, and only a small number of cross-border e-commerce giants have access channels. The construction of the Shanghai free trade zone has greatly improved this situation. Through the cross-border ecommerce platform, overseas small and medium-sized enterprises can show their products directly in front of Chinese consumers It greatly saves the cost of early marketing and promotion.

\section{Analysis of the Impact of E-Commerce on the Import and Export Trade of Shanghai Free Trade Zone}

\subsection{Data Processing and Description}

In view of Wang Junjie's "empirical study on the impact of cross-border e-commerce in the free trade zone on China's foreign trade", the level of foreign trade and the development of cross-border e-commerce in the free trade zone are measured by the total amount of import and export trade and cross-border e-commerce in the province where the free trade zone is located. Similarly, this paper selects the latest data of 2010-2019, selects the total amount of import and export trade of the municipality directly under the central government where the Shanghai free trade zone is located to measure the level of foreign trade of the free trade zone, and selects the amount of e-commerce trade of the municipality directly under the central government where the Shanghai free trade zone is located to measure the level of e-commerce development of the free trade zone, including the amount of e-commerce trade of Shanghai and the amount of import and export trade of Shanghai. In order to establish the model, the transaction volume of ecommerce in Shanghai is $\mathrm{X}(100$ million yuan), and the import and export trade volume in Shanghai is Y (100 million yuan). Data samples are as follows:

Table 1: Data of e-commerce volume and import and export volume of Shanghai in 2010-2019

\begin{tabular}{|c|c|c|}
\hline particular year & $\begin{array}{c}\text { Trading volume } \\
\text { of e-commerce } \\
\text { in Shanghai }(\mathbf{X})\end{array}$ & $\begin{array}{c}\text { Import and export } \\
\text { trade volume of } \\
\text { Shanghai }(\mathbf{Y})\end{array}$ \\
\hline 2010 & 4253 & 3293 \\
2011 & 5508 & 27625 \\
2012 & 7816 & 27570 \\
2013 & 10560 & 27846 \\
2014 & 13549 & 29405 \\
2015 & 16452 & 28061 \\
2016 & 20049 & 28664 \\
2017 & 24263 & 32238 \\
2018 & 28938 & 34010 \\
2019 & 33186 & 34047 \\
\hline
\end{tabular}

Data source: Shanghai Bureau of statistics, Shanghai Municipal Commission of Commerce, China E-Commerce Research Center

\subsection{Model Building and Testing}

In the part of cointegration test, this paper establishes a linear regression model, which is a kind of linear model. It is a model established by regression analysis to reveal the causal relationship between variables in economic phenomena.

The regression model is set as follows:

$$
\mathrm{LNY}=\beta 0+\beta 1 \mathrm{LNX}+\varepsilon
$$

LNY is the logarithm of Shanghai's import and export trade volume, which is the dependent variable. LNX is the logarithm of e-commerce transaction volume in Shanghai, which is an independent variable. $\beta 0$ is constant, $\beta 1$ is coefficient of explanatory variable, and $\varepsilon$ is random error term.

The variables in the model are logarithm of $\mathrm{X}$ and $\mathrm{y}$, because the logarithm of data does not change the nature and correlation of data. Therefore, the model reflects the impact of the development of e-commerce on the import and export trade of Shanghai free trade zone. 


\subsubsection{Correlation Analysis}

According to the data of Shanghai's e-commerce transaction amount $\mathrm{X}$ and Shanghai's import and export trade amount $\mathrm{Y}$ from 2010 to 2019 , we can see that the transaction amount of Shanghai's e-commerce is increasing year by year, and the overall trend of import and export trade amount is also increasing. From the figure, we can see that the development of Shanghai's foreign trade has a strong convergence with the growth of its e-commerce.

Table 2: Correlation coefficient of $X$ and $Y$

\begin{tabular}{|c|c|c|}
\hline & $\mathbf{X}$ & $\mathbf{Y}$ \\
\hline $\mathrm{X}$ & 1 & 0.917598 \\
$\mathrm{Y}$ & 0.917598 & 1 \\
\hline
\end{tabular}

Use Eviews10 software to analyze the correlation between $\mathrm{X}$ and $\mathrm{Y}$, calculate the correlation coefficient of $\mathrm{X}$ and Y, and get Table 2. According to Table 2, we can see that the correlation coefficient of $\mathrm{X}$ and $\mathrm{Y}$ is close to 1 , which shows that there is a strong correlation between $\mathrm{X}$ and $\mathrm{Y}$.

\subsubsection{Unit Root Inspection}

In order to eliminate the problem of heteroscedasticity, the data were logarithmically processed to get LNX and LNY. In addition, the time series is easy to produce the pseudo regression phenomenon, that is, there may be no real economic relationship between the two variables, but due to the consistent trend of change, the false regression phenomenon is formed, which can not truly reflect the relationship between variables. Therefore, it is necessary to test the stability of LNX and LNY sequences. In this paper, ADF test is used to test the stability of LNX and LNY by eviews10 software.

Table 3: Unit root test results

\begin{tabular}{|c|c|c|c|c|c|}
\hline variable & ADF value & $\mathbf{1 \%}$ t-Statistic & $\mathbf{5 \%}$ t-Statistic & $\mathbf{1 0 \%}$ t-Statistic & conclusion \\
\hline LNX & -0.010067 & -2.886101 & -1.995865 & -1.599088 \\
D (LNX, 1) & -0.995151 & -2.886101 & -1.995865 & -1.599088 \\
D (LNX, 2) & -2.941190 & -2.937216 & -2.006292 & -1.598068 & -1.600140 \\
instable & -1.988198 & -1.599088 \\
D (LNY, 1) & 1.877910 & -2.847250 & -1.995865 & stable & instable \\
D (LNY, 2) & -3.632559 & -2.886101 & -2.021193 & & -1.597291 \\
\end{tabular}

Note: $D(L N X, 1)$ represents the first-order difference of LNX, D $($ LNX, 2) represents the second-order difference of LNX, and so on

From the conclusion in Table 3, we can see that LNX and LNY are stable after second-order difference. Therefore, we can further verify the relationship between LNX and LNY in the long term through cointegration test.

\subsubsection{EG Cointegration Test}

According to the unit root test, LNX and LNY sequences are second-order integers. In this paper, the eg two-step method is used to test whether there is a long-term equilibrium relationship between the two sequences: the first step should be to determine that the two sequences are of the same order and single integer, and the above has determined that both sequences are of the second order and single integer; the second step is to carry out regression analysis on variables and unit root test on residual sequences. In order to obtain the residual, the OLS regression method is used to estimate the regression model, and table 4 is obtained through eviews 10:

Table 4: Regression analysis results

\begin{tabular}{|c|c|c|c|c|}
\hline Variable & Coefficient & Std. Error & t-Statistic & Prob. \\
\hline$\stackrel{\text { C }}{\text { INX }}$ & $\begin{array}{l}8.879760 \\
0.147089\end{array}$ & $\begin{array}{l}0.240031 \\
0.025177\end{array}$ & $\begin{array}{l}36.99415 \\
5.842217\end{array}$ & $\begin{array}{l}0.0000 \\
0.0004\end{array}$ \\
\hline \multicolumn{2}{|c|}{$\begin{array}{c}\text { R-squared } \\
\text { Adjusted R-squared } \\
\text { S.E. of regression } \\
\text { Sum squared resid } \\
\text { Log likelihood } \\
\text { F-statistic } \\
\text { Prob(F-statistic) }\end{array}$} & $\begin{array}{l}0.810118 \\
0.786383 \\
0.052970 \\
0.022446 \\
16.30665 \\
34.13150 \\
0.000386\end{array}$ & $\begin{array}{l}\text { Mean dependent var } \\
\text { S.D. dependent var } \\
\text { Akaike info criterion } \\
\text { Schwarz criterion } \\
\text { Hannan-Quinn criter. } \\
\text { Durbin-Watson stat }\end{array}$ & $\begin{array}{r}10.27866 \\
0.114607 \\
-2.861329 \\
-2.800812 \\
-2.927716 \\
1.638562\end{array}$ \\
\hline
\end{tabular}

The estimated regression model is:

$\mathrm{LNY}=8.879760+0.147089 \mathrm{LNX}$
$\begin{array}{cc}(36.99415) & (5.842217) \\ \mathrm{R}^{2}=0.810118 \quad \mathrm{~F}=34.13150\end{array}$


Therefore, there is a positive correlation between the total amount of e-commerce transactions in Shanghai and the total amount of import and export trade. For each unit of LNX growth, the LNY growth is 0.147089 units. It shows that the e-commerce transaction of Shanghai free trade zone is conducive to the development of its import and export trade. Save the residuals and name them, and carry out ADF test on the residuals sequence.

Table 5: ADF test results of residual sequence

\begin{tabular}{|c|c|c|c|}
\hline & & t-Statistic & Prob. \\
\hline Augmented Dickey-Fuller & test statistic & -3.863964 & 0.024 \\
\hline & $1 \%$ level & -4.582648 & \\
Test critical values: & $5 \%$ level & -3.320969 & \\
& $10 \%$ level & -2.801384 & \\
\hline
\end{tabular}

According to table 5, it shows that at 5\% significance level, the original hypothesis is rejected, so the residual sequence is stable, so there is an equilibrium relationship between LNX and LNY, and it is proved to be a cointegration relationship.

\subsubsection{Error Correction Mode}

In order to enhance the accuracy of the regression model and determine the short-term relationship between LNX and LNY, this paper uses eviews10 software to establish a short-term dynamic model, so as to make up for the shortcomings in the long-term static model, in which ECM is the error correction term, which is the residual term in the OLS regression estimation model. The results are shown in Table 6:

Table 6: Error correction model test results

\begin{tabular}{|c|c|c|c|c|}
\hline Variable & Coefficient & Std. Error & $\mathrm{t}-\mathrm{St}$ & Prob. \\
\hline $\begin{array}{c}\mathrm{C} \\
\mathrm{D}(\mathrm{INX}) \\
\mathrm{ECM}(-1)\end{array}$ & $\begin{array}{c}-0.019040 \\
0.257014 \\
-0.932695\end{array}$ & $\begin{array}{l}0.074047 \\
0.312327 \\
0.401548\end{array}$ & $\begin{array}{l}-0.2 \\
0.8 \\
-2.3\end{array}$ & $\begin{array}{l}0.8057 \\
0.4420 \\
0.0592\end{array}$ \\
\hline $\begin{array}{c}\text { R-squared } \\
\text { Adjusted R-squared } \\
\text { S.E. of regression } \\
\text { Sum squared resid } \\
\text { Log likelihood } \\
\text { F-statistic } \\
\text { Prob(F-statistic) }\end{array}$ & & \multicolumn{2}{|c|}{$\begin{array}{l}\text { Meandependentvar } \\
\text { S.D. dependentvar } \\
\text { Akaike infcriterion } \\
\text { Schwarz criterion } \\
\text { Hannan-Quinn criter. } \\
\text { Durbin-Watson stat }\end{array}$} & $\begin{array}{c}0.042177 \\
0.066583 \\
-2.673423 \\
-2.607681 \\
1.101987\end{array}$ \\
\hline
\end{tabular}

The error correction equation is:

$$
\begin{aligned}
& \triangle \mathrm{LNY}_{\mathrm{t}}=0.257014 \triangle \mathrm{LNX}_{\mathrm{t}}-0.932695 \mathrm{ECM}_{\mathrm{t}-1} \\
& \mathrm{R}^{2}=0.473543 \mathrm{~F}=2.698470
\end{aligned}
$$

The coefficient of the error correction term indicates that $93.27 \%$ of the equilibrium errors in LNX and LNY in the previous period have been corrected in this period, and the interaction between them is relatively large in the short term. In addition, the change of LNY is not only related to the change of LNX in this period, but also related to LNY in the previous period.

\subsubsection{Granger Causality Test}

Granger causality test can well explain that the change of $\mathrm{Y}$ is caused by the change in the early $\mathrm{X}$. One of the preconditions of Granger causality test is that the test data must be stable, otherwise there may be pseudo regression. In this paper, the unit root test has been used to verify that the data is stable. According to the AIC and $\mathrm{SiC}$ information criteria, the optimal lag length is 1 . The Granger causality test using eviews 10 software is shown in Table 7 :

Table 7: Granger causality test results

\begin{tabular}{|l|c|c|c|}
\hline $\begin{array}{c}\text { granger } \\
\text { causality }\end{array}$ & F value & P value of $\mathbf{F}$ & conclusion \\
\hline Y is not the & & & \\
cause of $X$ & 0.24168 & 0.6405 & accept \\
$X$ is not the & 8.23044 & 0.0285 & refuse \\
cause of $Y$ & & & \\
\hline
\end{tabular}


In order to better reflect the relationship between variables, the Granger causality test is carried out. The test results are as follows: the total amount of e-commerce is the reason to promote the total amount of import and export trade in Shanghai, but the total amount of import and export trade in Shanghai is not the reason to promote the total amount of e-commerce.

\subsection{Empirical Results and Analysis}

Through the above tests, we can see that there is a correlation between $\mathrm{X}$ and $\mathrm{Y}$. It is concluded that the development of e-commerce has a positive role in promoting the import and export trade of Shanghai free trade zone.

\section{Conclusions and Policy Recommendations}

\subsection{Research Conclusion}

The construction of Shanghai free trade zone has expanded China's opening to the outside world and promoted the development of foreign trade. The construction of Shanghai free trade zone and various guidance documents and preferential policies of the government for the development of e-commerce provide a good policy environment and support for the application of e-commerce in foreign trade, the development of industry and the improvement of regulatory system. Through empirical analysis, we can see that there is a correlation between Shanghai's import and export trade volume and its e-commerce trade volume, and it is proved to be a longterm co integration relationship. Compared with the longterm, the equilibrium fluctuation of the two variables is greater in the short term. It can be seen from the error correction equation that the change of Shanghai's import and export trade volume is not only related to the change of e-commerce trade volume in the current period, but also related to the import and export trade volume in the previous period. The above analysis shows that e-commerce plays a positive role in promoting the import and export trade of Shanghai free trade zone. Therefore, the government should take relevant measures to promote the development of e-commerce and the transformation of foreign trade enterprises, so as to promote the development of foreign trade. Foreign trade enterprises should use ecommerce platform to adapt to the development of the times. The construction of Shanghai free trade zone is in the process of exploration. Policy innovation and e-commerce platform construction are carried out in the pilot window of Shanghai Free Trade Zone, and the replicable experience is promoted in combination with the local actual situation.

\subsection{Suggestions on Promoting the Development of E-Commerce in Shanghai Free Trade Zone}

\subsubsection{Create an Environment Conducive to the Operation of E-commerce}

The problem that must be solved in the development of e-commerce is the security and reliability of transactions. $\mathrm{Xu}$ Wei put forward the policy suggestions to improve the e-commerce in China's international trade in the article "the impact of e-commerce on international trade". He believed that in the macro aspect, we should strengthen the network supervision, guarantee the information security and create an environment conducive to the operation of e-commerce. This paper also agrees with this view. For the construction of e-commerce platform in Shanghai Free Trade Zone, online payment has become a common phenomenon. If there are network security problems, especially payment security problems, consumers will have doubts about the security of the platform, not to mention that international trade is cross-border, and security is the primary consideration for both sides of the transaction. Therefore, the Shanghai municipal government should strengthen the network supervision, crack down on the use of the network for illegal and criminal activities, and safeguard the legitimate rights and interests of enterprises and consumers. The e-commerce platform should recruit relevant network security personnel for network security maintenance, prevent the leakage of user information and other situations, and increase the security factor of e-commerce transaction.

\subsubsection{Establish E-commerce Talent Training System}

Looking up the latest relevant research literature, without exception, it is pointed out that the lack of e-commerce talents in China, so that the government should take positive measures to speed up the cultivation of talents. Therefore, it can be seen that there is a general lack of foreign trade talents in all regions of China, especially those who are proficient in foreign trade and international ecommerce. The Ministry of education of China should pay attention to it and train relevant e-commerce talents as soon as possible. Specifically, the Shanghai municipal government can encourage the universities and social Universities of the city to carry out systematic e-commerce talent training programs, improve the cross-border ecommerce talent incentive mechanism, and lay the foundation for the development of e-commerce in the Shanghai free trade zone. In addition to recruiting professional and relevant skilled talents, Shanghai foreign trade enterprises can also carry out targeted training for employees to master the basic electricity Sub business skills. 


\subsubsection{Systematization of Logistics Construction and Information Construction}

In terms of logistics construction, the government should vigorously support its construction, so as to greatly reduce the cost and establish sound infrastructure. In the empirical study on the impact of cross-border e-commerce in free trade zone on China's foreign trade, Wang analyzed the existing problems in each link of cross-border logistics, and combined with the advantages of free trade zone, put forward two aspects to promote the development of crossborder logistics in free trade zone, including continuous improvement of cross-border logistics integrated service platform and enhancement of overseas storage capacity. This paper holds that the same should be true for the construction of Shanghai Free Trade Zone in terms of logistics. First, we should continue to improve the construction of cross-border Logistics comprehensive service platform. We should take Shanghai free trade zone as the core, link to the cross-border e-commerce platform of the country where the trading partner of Shanghai free trade zone is located, and improve the service level of crossborder e-commerce in Shanghai free trade zone. Secondly, the overseas storage capacity should be improved. When the buyer orders and orders, the seller can deliver goods directly from the buyer's country, which greatly saves the logistics time. Finally, we should improve the professionalism of cross-border logistics services, and use existing technology to establish an intelligent logistics warehousing system.

\subsubsection{Enterprises Should Change Their Ideas to Adapt to the International Trade Environment}

The transformation and modernization of China's foreign trade enterprises started late, and the application of ecommerce in the international trade industry was limited. Therefore, in order to realize the benign development of foreign trade enterprises, enterprises should fully realize the application value of e-commerce. Tan Chi, a scholar, in the study on the impact of e-commerce on China's international trade and development countermeasures, puts forward the relevant problems of enterprise's internal information construction, promotes the innovation of enterprise management mode, and provides conditions for the further smooth development of e-commerce. This paper holds that foreign trade enterprises in Shanghai free trade zone should employ high-end Internet technical personnel by taking advantage of regional advantages, carry out enterprise information construction in combination with their own actual situation, and then carry out e-commerce development with the help of information promotion, so as to achieve the purpose of saving time and cost, improving international competitiveness and adapting to the development trend of modern international trade.

\section{References}

Fan, M. G. (2019). Analysis of the impact of e-commerce on international economic and trade and countermeasures. Chinese and Foreign Entrepreneurs, 17, 89.

Gessner, G. H., \& Snodgrass, C. R. (2015). Designing ecommerce cross-border distribution networks for small and medium-size enterprises incorporating Canadian and u.s. trade incentive programs. Research in Transportation Business \& Management, 16, 84-94.

Geomina, Turlea, Estrella, Gomez-Herrera, Bertin, \& Martens. (2014). The drivers and impediments for cross-border ecommerce in the eu. Information Economics \& Policy, 28, 8396.

Huang, S. L., \& Chang, Y. C. (2019). Cross-border e-commerce: consumers' intention to shop on foreign websites. Internet Research, 29(5), 1256-1279.

Rong, J., \& Zhong, D. J. (2018). Influence factors of customer satisfaction in cross-border e-commerce. Journal of Discrete Mathematical Sciences and Cryptography, 21(6), 1281-1286.

Qiao, Y., Shen, M., Liu, J., Yang, G., \& Yue, Q,. (2012). Analysis of the impact and application of e-commerce on international trade. Foreign Trade and Economic Cooperation, 03, 39-41.

Tan, C. (2019). Research on the influence of e-commerce on China's international trade and development strategies. Business News, 24, 154-155.

Terziaa, N. (2011). The impact of e-commerce on international trade and employment. Procedia - Social and Behavioral Sciences, 24, 745-753.

Wang, J. J. (2018). Empirical Study on the impact of cross-border e-commerce in free trade zone on China's foreign trade. Doctoral dissertation, Shenyang University of Technology. Shenyang, China.

Zou, Y., Zhou, L., Zou, X. Y., \& Yuan, R. L. (2014). Development status and suggestions of e-commerce in Shanghai Free Trade Zone. Modern economic information, 20, 399-400. 